DOI: $10.20472 / S S .2018 .7 .2 .004$

\title{
POST-WORLD WAR II FORCED REPATRIATIONS TO YUGOSLAVIA: GENOCIDE'S LEGACY FOR DEMOCRATIC NATION BUILDING
}

\author{
DOROTHY S. MCCLELLAN, NIKOLA KNEZ
}

\begin{abstract}
:
This paper examines the long-term challenges to democratic nation building that have resulted from the forced repatriation of hundreds of thousands of Croatian civilians and military personnel to Yugoslavia at the end of World War II. Data suggest that violations of the Geneva Conventions led to the death of many of these asylum seekers at the hands of Tito's Partisans in death marches and mass executions. Through analysis of historical documents, newly released evidence of mass graves, and interviews with survivors/witnesses, confessed perpetrators, military officials and scholars, we examine the atrocities in the context of international human rights law, with discussion of subsequent promulgation of protocols for the protection of refugees, asylum seekers, and prisoners of war from crimes against humanity and genocide.
\end{abstract}

\section{Keywords:}

forced repatriation, genocide, international law, democracy, violations of international law, Geneva Conventions, asylum seekers, communist crimes, Yugoslavia, human rights, prisoners of war

JEL Classification: K33, K42, D74

\section{Authors:}

DOROTHY S. MCCLELLAN, Texas A\&M University-Corpus Christi, United States, Email: dorothy.mcclellan@tamucc.edu NIKOLA KNEZ, 21st Century Society for Human Rights \& Education, United States, Email: nikolaknez@ifilms-fx.com

\section{Citation:}

DOROTHY S. MCCLELLAN, NIKOLA KNEZ (2018). Post-World War II Forced Repatriations to Yugoslavia: Genocide's Legacy for Democratic Nation Building. International Journal of Social Sciences, Vol. VII(2), pp. 62-91., 10.20472/SS.2018.7.2.004 


\section{Introduction}

At the end of World War II, despite the victory of the Allies in Europe and the official defeat of fascism, the secret killing continued as organized groups of victors in Yugoslavia sought revenge against suspected foes.

This article examines the long-term challenges to democratic nation building engendered by forced repatriation of hundreds of thousands of people to Yugoslavia after World War II. Through analysis of historical documents, newly released evidence of mass graves, and interviews conducted with survivors, confessed perpetrators, British officers, scholars, and military intelligence officials, we trace the forced repatriation to Yugoslavia of as many as 700,000 Croatian civilians and military personnel who unsuccessfully sought asylum from the British in occupied Austria in May 1945. Data suggest that violations of the Geneva Conventions led to the death of many of these individuals at the hands of Yugoslav Partisans. No one has yet been held to account.

The majority of the refugees who were repatriated were killed under conditions of indiscriminate savagery in Josip Broz Tito's notorious death marches and mass executions. We examine the atrocities in the context of international human rights law, with discussion of the subsequent promulgation of protocols on crimes against humanity, and the protection of refugees, asylum seekers, and prisoners of war. Revealing the longhidden truth and enforcing international law to protect against future atrocities are steps in the direction of societal reconciliation and renaissance.

\section{The Broad Goals of the Project: Seeking Justice}

While in Croatia as a Fulbright scholar 2002-2004 and 2012, Dr. Dorothy McClellan, Regents Professor of Criminal Justice, Texas A\&M University-Corpus Christi, undertook a multi-faceted international collaborative project with Nikola Knez, filmmaker and President of the Croatian Society for Human Rights, examining challenges to democratic nation building in post-conflict society. Over the course of the Fulbright fellowships and beyond, the focus of their work has been on the Croatian War for Independence 1991 1995 and its aftermath. With the recent release of documents, investigative reports, and physical evidence of mass killing at the end of World War II, their examination of the challenges to democratic nation building has extended back in time to 1945 . The events addressed in this article suggest that a crisis of conscience related to post-World War II mass genocide in Slovenia, Croatia and Bosnia and Herzegovina, rarely discussed or mentioned in the literature, continues to contribute to the political, economic and moral instability/insecurity of the region.

The overarching goals of the project are:

- To give voice to the people who were victims of crimes of totalitarian regimes.

- To seek formal governmental acknowledgment of the crimes committed. 
- To use the testimony of victims and recently disclosed confirmation of crimes to raise public awareness of the need to end governmental corruption, suppression of evidence, and the perpetuation of the myth that no crimes were committed.

- To bring the perpetrators to justice.

- To encourage public policy initiatives that focus on democratic nation building, transparency, and transfer of power away from old elites in an attempt to disassemble undemocratic practices that continue to plague the countries of the former Yugoslavia.

\section{Methodology}

Employing an activist qualitative research methodology that includes interviews with survivors/witnesses, confessed perpetrators, British officers, scholars, and military intelligence officials, we sought to examine the legal, political, psychological and social consequences of what has come to be called 'The Bleiburg Massacre' and 'Operation Slaughterhouse' (Prcela and Guldescu, 1995). The point of this methodology is to engage in research that brings about the empowerment of the people being studied, that respects and includes them in the process, and that reaches a broad audience on issues that touch the lives of many in society and require an effective public policy response. Activist research requires that analytical categories be subjected to critical scrutiny, that the knowledge produced be "situated" in facts and human experience, and that the products be broadly disseminated (Haraway 1988, p. 574; Hale 2001, p. 14). In the spirit of this methodology, the products we create are multi-faceted and aim to reach the academic community, international scholarly and political circles, lawmakers, as well as the general public. These products include investigative reports in the media, academic journal articles, presentations at international conferences, archival collection of recorded testimony, as well as documentary and feature film.

We began this project by reviewing the literature and interviewing principals to understand the extent and nature of the post-World War murders of large numbers of individuals by Partisan forces, the roots of the unwillingness of governmental authorities to release information and to prosecute the victimizers, as well as the reluctance of victims to step forward to share their experiences and name names. To date there are few scholarly works, documentary films or investigative inquiries in the media that touch on this topic, that reveal the long-undisclosed truth. Evidence of the crimes remains hidden at secret gravesites across the former Yugoslavia.

Documentary film is now integral to academic pedagogy and a powerful tool to reach broad audiences, so a major aspect of this study was to produce a documentary film that relies on interviews with survivors, experts, and perpetrators. In addition, we have written a feature film screenplay that is a fictionalized account of actual events, that we expect will go into production in the near future. The screenplay was awarded a Gold Remi by WorldFest International Film Festival in April 2017. The feature film aims to reach an even broader international audience. 
The documentary film, entitled Bleiburg: Tito's License for Genocide, based on the interviews and research, was completed in June 2017. Since the interviews were conducted in multiple languages (Croatian, Slovenian, Serbian, German and English), we undertook the production of both an English language and a Croatian language version of the documentary to gain international recognition of the problem. Our cast for the English language voiceovers was drawn from twelve highly respected American lawyers, public officials, and professionals in the community. The premiere of the film in the U.S. is scheduled for 2018 at the U.S.S. Lexington Museum with public officials presiding and the cast for the English language film present. The documentary received two Special Jury Remi Awards at WorldFest International Film Festival in April 2018, one for film production, the other for the screenplay, placing it among the top ten of 4500 entries.

Working with the non-governmental organization, Platform of European Memory and Conscience in Prague, we are aiming to screen the film at an upcoming meeting of the organization. We are in communication with members of the Political Affairs Committee of the Parliamentary Assembly of the Council of Europe that drafted Resolution 1481, Condemnation of Crimes of Totalitarian Regimes. While the resolution did not achieve the $2 / 3$ majority vote required for adoption by the full Assembly in 2006 , we hope that our project will assist in promoting its reintroduction.

The Fulbright Association invited us to give two presentations on forced repatriation at the 40th Anniversary of the Fulbright Association Conference in Washington, D.C. in November 2017. In addition, the authors participated in the 32nd International Academic Conference of the Institute for Social and Economic Sciences in Geneva in June 2017, presenting a paper on international law violations and the Bleiburg massacre at the close of World War II. The presentations included excerpts from the authors' documentary film, Bleiburg: Tito's License for Genocide (Knez 2017).

\section{$4 \quad$ Historical and Political Background}

On Bleiburg Field in southern Austria, the great deception began. According to records of the British Foreign Office, 200,000 Croatian and Slovenian soldiers and military personnel, as well as 500,000 civilians headed to Bleiburg at the end of World War II seeking asylum, expecting that the British would abide by the principles of the Geneva Conventions and provide them sanctuary to protect them from Partisan reprisals (Figure 1) (Sviben 1995, p. 153; British Foreign Office Headquarters 5th Corps). Most of the refugees left the Croatian capital of Zagreb on 7 May 1945. A column of people approximately 70 kilometers long was reported by Radio London to be moving north to Austria from Croatia and Bosnia and Herzegovina, people scrambling to leave Yugoslavia, "overtaken by a fear of the Partisan units"... [whose] brutality, crimes, and desire for retaliation were known and documented" (Obrdalj 1995, p. 297; Portmann 2004, p. 68; Lowe 2012, p. 253). Grahek-Ravančić reports that this sentiment is expressed in numerous personal eyewitness accounts (2006, p. 32. See also Obrdalj 1995, pp. 130134). The Partisan units "were known for their brutality, crimes and wickedness" (Obrdalj 1995, 130-134; Prcela and Guldescu 1995, pp. 125-535). 
Figure 1: British Foreign Office Headquarters 5th Corps Report on Refugees

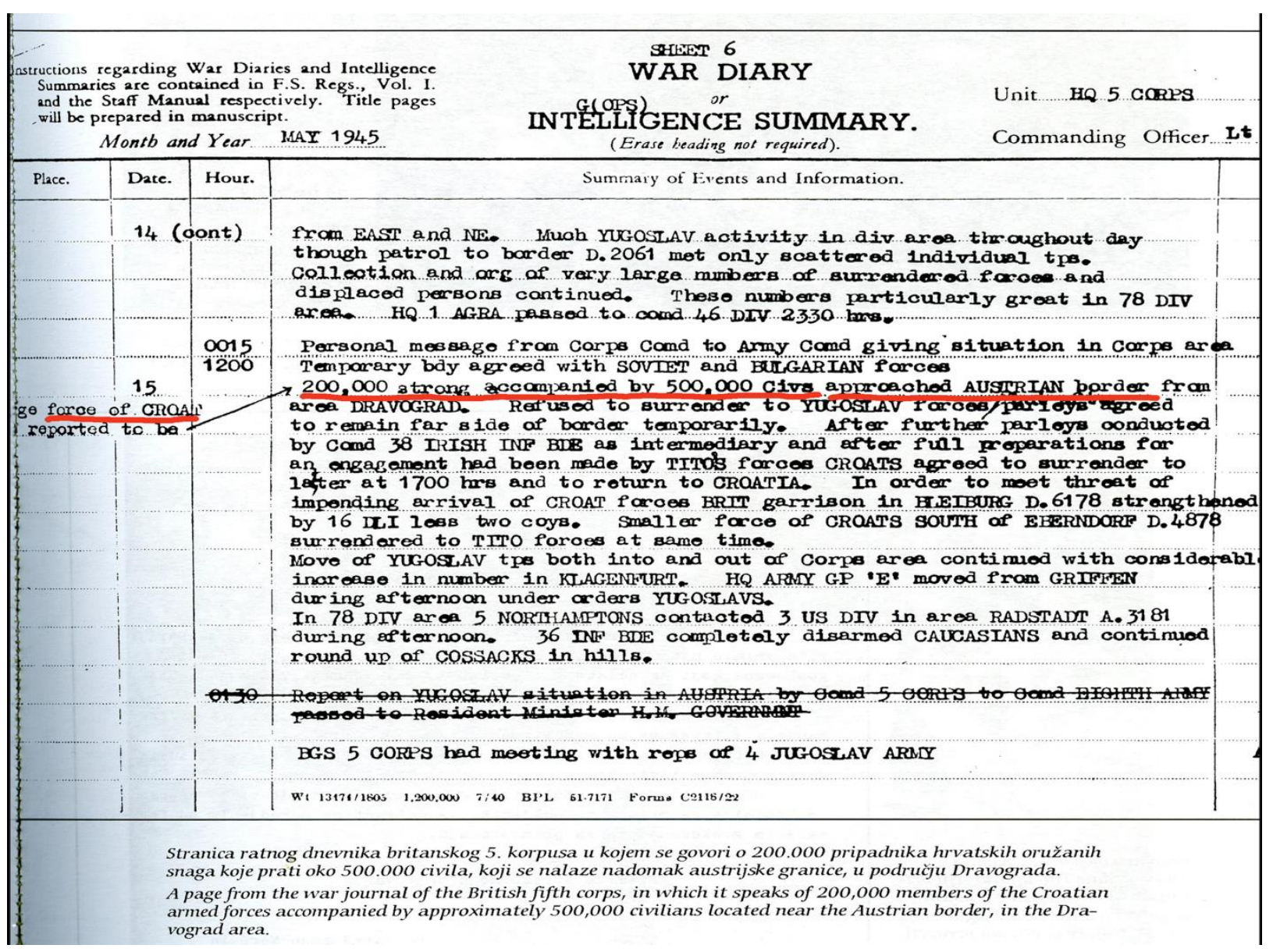

Source: Sviben 1995, p. 153

Historian Grahek-Ravančić explains that according to British army records, "On the evening of 14 May, a Croatian Liaison Officer arrived at the headquarters of the 38th Irish Infantry Brigade and informed it that 'two groups of Croats, each of about 100,000 men under arms,' with 'about 500,000 civilians' were arriving in the area" (Grahek-Ravančić 2006, p. 32; Jareb and Omrčanin 1977-1978, p. 51). John Ivan Prcela, the renowned Bleiburg historian, was among them. He recounts: "More than a half million Croatians moved toward Austria with the hope of surrendering to the civilized Western allies" (in filmed interview January 2017).

Tomislav Obrdalj walked in that long column on the road to Bleiburg, accompanied by a fellow graduate student when "on the 15th of May British spitfires flew overhead." The British "probably photographed the enormous mass of people already on the field before us" (1995, p. 297). Dr. Martin Hrgovčić, the fellow graduate student, now a renowned Croatian-American oncologist and hematologist, recalled, "Close to Celje, in the city named Slovenj Gradec, two British airplanes were flying at a relatively low altitude. We hid ourselves into a side place covered by tall grass to hide from the airplanes." Pointing to the original $\mathrm{x}$-ray which he has saved all these years, he said, "They opened fire and I 
could hear very well when a bullet hit the sole of my left foot" (in filmed interview March 2017).

In the report of a local British commander,

(a) National emigration in progress with the object of surrendering to British Army. Numbers involved about 1 million now approaching BLEIBURG, including two Army Corps of approx 100.000 each, arrived but short of ammunition.

(b) Their surrender has been refused and they are not to cross the old Austrian frontier. They have been so informed and warned we intend to use force of arms to enforce our decision (Jareb and Omrčanin 1977-1978, pp. 25-26; Blažeković, 1988, pp. 405-406).

According to Croatian Colonel Danijel Crljen, the escaping population created a "human wall which ... eliminated any possibility to proceed," enabling the Partisans to completely encircle them (Crljen 1966, p. 270).

On 15 May, "after eight days of wandering, hunger, and struggle" in this mass exodus, the refugees arrived at Bleiburg (Ljerkić 1963, p. 101). The British, Partisan, and Independent State of Croatia armies met on the field at Bleiburg. On the afternoon of the same day, the Croatian forces raised white flags of surrender (Grahek-Ravančić 2008, p. 543). Negotiations were held at Bleiburg Castle (Rulitz 2015, p. 38). NDH (Independent State of Croatia) military representatives attempted to negotiate a surrender to the British, but were directed to surrender to the Yugoslav military (Tomasevich 2001, p. 758). Brigadier Thomas Patrick Scott of the 38th (Irish) Infantry Brigade was the British negotiator (Grahek-Ravančić 2008, p. 535). He was ordered to tell the Croatians to refrain from advancing further. "During this conversation, the Croatian delegation was allegedly promised that they would be able to proceed freely" to safe zones in Italy on the following day if they surrendered their weapons (Grahek-Ravančić 2006, p. 32; Crljen 1966, p. 283; Tolstoy 1986, p. 139; Vlahović 1985, p. 357).

Yet, "Scott notes in his diary (Figure 2) that he was told by a higher authority that on no account could any British officer accept an offer to surrender, because the Croatians 'had fought against the Yugoslavs in support of Germany and they must become Yugoslav prisoners'" (Grahek-Ravančić 2006, p. 32; Jareb and Omrčanin 1977-1978, p. 52). Scott told Colonel Crljen that he had orders from British Field Marshal Harold Alexander, who had received "precise political instructions from Prime Minister Churchill" (GrahekRavančić 2006, p. 34; Crljen 1966, p. 287).

British historian Count Nikolai Tolstoy writes that "Churchill proved to be in full agreement with the course suggested, replying [already] on 29 April [to British Ambassador to Belgrade Ralph Stevenson] to the effect that, 'There is no doubt that...they should be disarmed and placed in refugee camps, is the only possible solution'" (Tolstoy 1986, p. 8). Tolstoy suggests that there was a conspiracy regarding the extradition of many Soviet citizens and Yugoslavs in which later Prime Minister Harold Macmillan played a key role. On 12 May, Macmillan met in Italy with British Field-Marshal Harold Alexander. Macmillan 
then came to Klagenfurt in Bleiburg where he met with the British Command Center (Tolstoy 1986, p. 111). Two days later, on 14 May, British command ordered that "all surrendered personnel of established Yugoslav nationality who were serving in German forces should be disarmed and handed over to Yugoslav forces and the tens of thousands pouring across the border should be disarmed and forced to return to Yugoslavia" (Tolstoy 1986, p. 112).

\section{Figure 2: Scott's Diary}

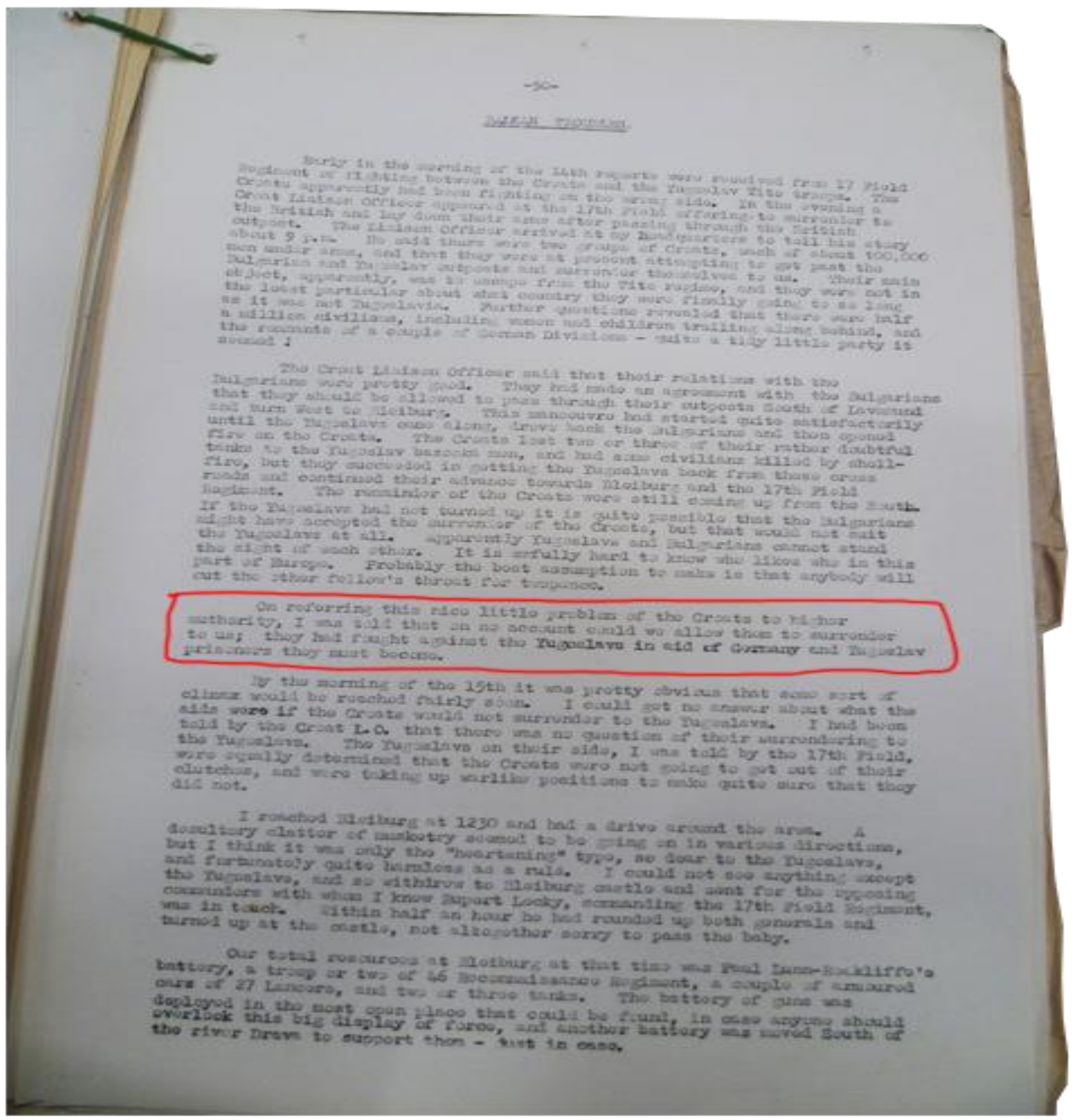

Source: Nigel Nicolson's Papers 
Crljen, one of the three Croatian negotiators, in his account of the events writes that Scott told the Croatian delegation:

You are surrounded by powerful forces of the Yugoslav army.... It is in your best interest to consent to capitulation and save all the refugees.... An hour after you return to the units the capitulation deadline begins.... Civilian refugees will be repatriated and sent home; if you consent to our terms, your whole army will be placed in captive camps under the protection of international law for human rights and protection of prisoners of war. [Turning to the Partisan negotiators] My tanks are at your disposal.

Crljen writes that the Croatians requested that the British commission be present during extradition, but Scott replied: "You cannot demand anything. This concerns only our Allies, if they want us to be there." Scott reportedly warned the Croatians that if they did not immediately surrender, "we will start bombing you after one hour" (Crljen, pp. 292293; Grahek-Ravančić, 2006, pp. 45-46). According to Croatian Bleiburg survivor, Andy Mihaljević, "After a few days of negotiating with the British, our Croatian commander made the decision and gave the order, that we were to lay down our weapons.... Chaos ensued" (in filmed interview September 2016).

Grahek-Ravančić concludes that "During the negotiations, reference was often made to the regulations of The Hague and Geneva Conventions which determine the treatment of prisoners of war" (2006, pp. 35-36). However, according to the Yalta Conference Declaration of 1945, the Allies had already "decided that all prisoners who were Soviet citizens and had belonged to enemy formations supporting the Third Reich should be handed over to the country they had fought against." The Yalta Conference, code-named the Argonaut Conference, held from February 4 to 11, 1945, was the World War II meeting of Soviet Premier Joseph Stalin, British Prime Minister Winston Churchill, and U.S. President Franklin D. Roosevelt convened at Livadia Palace near Yalta in Crimea, Soviet Union to discuss Europe's postwar reorganization. In exchange for its Soviet citizens, the Soviet government agreed to hand over several thousand western Allied prisoners of war whom they had liberated from German prisoner of war camps (Sanders et al. 1992, vi). C. Michael McAdams argues that "Although the Yalta agreement included only Soviet citizens, it was supported by each of Stalin's protégés, including Josip Broz Tito" (1995, p. 95).

On May 17 Brigadier Toby Low of the 5th Army Corps in Secret Order 462 wrote:

All Jugoslav nationals at present in the Corps area will be handed over to Tito forces as soon as possible. These forces will be disarmed immediately but will NOT be told of their destination. Arrangements for the handover will be coordinated by this $\mathrm{HQ}$ in conjunction with [Communist] Jugoslav forces. Handover will last over a period owing to [logistic] difficulties of Jugoslav acceptance. Fmns will be responsible for escorting personnel to a selected point notified by the $\mathrm{HQ}$ where they will be taken over by Tito forces (WO. 170/4241, Appx J, Folio 28, Tolstoy, p. 138). 
Thus, after solemn assurances that they were being sent to safe zones in Italy, the British jammed the Croatians seeking asylum into military vehicles and railway cars and led them like sheep to the slaughter. Numerous memoirs confirm that as Croatian soldiers left the camp where they were held awaiting transfer, the British colonel gave a speech assuring them that in Italy they would be "reformed and dressed in new uniforms and trained for new tasks" (Prcela and Zivić 2001, p. 306). The refugees were betrayed. The trains and vehicles rolled back to the Slovenian border, not to Italy.

Many of the details of the negotiations and actions are recorded in privately held documents belonging to Capt. Nigel Nicolson, Intelligence Officer for the First Guards Brigade, who noted all details at length in the official Log Book "in which he entered hour by hour matters which it was his duty to record and report" (Tolstoy 1986, p. 11, pp. 3945). In filmed interview with Michael Palaich in 1988, British 8th Army Captain Nigel Nicolson was asked:

MP: Were you given orders from Corps Headquarters to the effect that all Croatians who were in the area at the time should be sent to Rosenbach via the Welsh Guard Brigade and that they in turn would be turned over to Tito's Partisans?

NN: Yes. Of course, the order didn't come direct to us from Corps. It came down the chain of command, so we received the orders from the 6th Armored Division, and we first got the order to which you refer on the sixteenth of May, but were told not to put it immediately into action and it was acted upon three days later, on the 19th of May, when we began to evacuate from Rosenbach and another small train station, Maria Elend, the first batches of the Croats and then for the next five days we organized train loads of Croats to go to Yugoslavia.

MP: Were the repatriated Croatians and the other ethnic groups called at the time antiYugoslavs, were they to be told exactly what their destination was?

NN: No. We received specific orders from our division that they were not to be told where they were going, as naturally, they were very anxious that they shouldn't be sent back to Yugoslavia and suspected this. We were told only a few days later that we were to tell them definitely they were going back to Italy.... And this lie, which we told with the greatest reluctance, was ordered from above. And, of course, if they'd learned the truth, that they were going back to Yugoslavia where they didn't expect to survive, none of them would have consented to mount the railway trucks. But as they trusted us that we were telling the truth, there wasn't much trouble about loading them on.

NN: There were 6,000 of them and we were ordered to send them to Yugoslavia. I remember asking for advice from the division: "Are we to send the civilians as well?" and the answer came back, "Yes if they are camp followers," and then I asked, "What is a camp follower?" and the reply was, "A camp follower is any person, however young or whatever sex, who is dependent upon the soldiery for their maintenance, for their livelihood." Well, that meant everybody. It is one of the most disgraceful operations 
British troops have ever been asked to undertake, and we felt that at the time, and many of us expressed it at the time. I expressed it in writing in a public document and was reprimanded for doing so.

Michael Palaich also carried out a highly charged filmed interview with British 8th Army Captain Colin Gunner in 1988.

MP: What was the discussion between the ordinary British soldier with regard to this whole business?

CG: Dirty. Yes, a dirty business in which we did not wish to be mixed up. A dirty, bloody, political business in which we did not want to be.... We were ashamed of it. Ashamed. We still are. We were ashamed of it. We are ashamed of one thing: That we didn't have the guts to say "fuck off." We were following orders! Jesus Christ... Ah, history.... If we had to do it again, I suppose we would. (Gunter breaks down.)

In recorded testimony by a Partisan soldier who defected to the British, and in 1953 gave testimony about his experiences, he states, "I was on Bleiburg field when English troops extradited Croatian soldiers with their families, women and children. After that, we Partisans took the people by train to Yugoslavia, through the tunnel in Jesenica" (Nigel Nicolson papers; Tolstoy 1986, p. 198-200; Prcela and Zivić 2001, pp. 390-394; Prcela and Guldescu 1995, pp. 370-377).

Andy Mihaljević explains that upon reaching Yugoslavia, "They placed us in an endless column and forced us to go on foot toward the city of Maribor. We walked all day. Actually, we had to move at a very fast pace. Partisans were on horseback and on bicycles. Whoever couldn't keep up, was beaten or shot" (in filmed interview September 2016).

In a 1979 interview with renowned journalist and researcher Dr. George Urban, Milovan Djilas, former Partisan commander and Vice President of the Federal Republic of Yugoslavia, states:

The great majority of the people the British forced back from Austria were simple peasants. They had no murders on their hands. They had not been Ustashis or Slovenian 'Home Guards'. Their only fear was of communism and the reputation of the communists. If the British had handed over to us 'quisling' leaders such as Nedić, and police agents who had collaborated with the Nazis in torturing and killing people, there could be no question of the morality of the British action. But this was not what they did. They forced back the lot -- and this was profoundly wrong (Tolstoy 1986, p. 355) (Urban 1979, p. 43).

In interview Djilas is asked by Dr. Urban: "Could the British authorities responsible have reasonably assumed that all the refugees would be massacred on return?" He responds: 
I think they ought to have had a pretty shrewd idea of what we'd be doing with them. We had a British Military Mission attached to us. Its members could have entertained no doubt as to how the Ustashis and Chetniks were treating us, and how we were treating their captured men and, in fact, anyone we remotely suspected of supporting them. But the British preferred to shut their eyes (Tolstoy 1986, p. 357; Urban 1979, pp. 40-42).

The Americans did eventually protest. The final order issued by the Americans on July 4, 1945 reads:

1) Yugoslavs should not be repatriated to Yugoslavia or handed over to Partisan troops against their will.

2) The Yugoslavs fighting against Tito will be treated like displaced persons and be transported to Camp Viktring...

3) These individuals will be considered to be displaced persons and will be transferred to Italy (Vetrinjska tragedija 1960, pp. 47-48; Grahek-Ravancic 2006, p. 42; Tolstoy 1986, pp. 125-126).

But the die had been cast. By then the repatriations of Croatians were a fait accompli and the flow of refugees had ceased. It should be noted that the forced repatriation of Soviet Armed Forces POWs of the Nazis to the Soviet Union was carried out in Northern Italy by British and American forces between 14 August 1946 and 9 May 1947, with similar consequences--most of those repatriated were imprisoned in forced labor camps or executed (Tolstoy 1979, p. 360; Epstein 1973).

According to the testimony of a Partisan soldier, the details of which were confirmed by yet another Partisan:

Then the orders came from the staff of the 11th Dalmatian Brigade that the most reliable communists, both officers and soldiers were to be chosen for a confidential task.... They created a special unit of them, which amounted to seventy people. Every day between 10 to 20 trains arrived at the station full of people. They didn't receive any food or water. The overwhelming majority of them were collapsing. Most were men. A smaller proportion were women who were raped in the pit before they were shot.... Two hundred boys from 14 to 16 years of age. Everyone was killed. All killed. In two pits. There were 30,000 to 40,000 killed in 8 days.... The Partisans went to Lake Bled on vacation on Sundays after eight days of killing, then came back for another round.... From Kočevja alone we sent over twenty freight cars of clothes. Daily we sent two to three freight cars of personal effects of the dead (Tolstoy 1986, pp. 198-200; Nicolson Log Book; Prcela and Guldescu 1995, pp. 370-379).

In filmed testimony of Serbian Partisan Commander Simo Dubajić, he states:

Tito decided to identify only Germans as prisoners of war, while members of other army units should be liquidated. Mass murdering was done by special Partisan 
units, KNOJ, the Peoples Liberation Army of Yugoslavia, and OZNA, a secret military Partisan unit (Dubajić 2005).

The majority of the refugees who were turned over to Tito were killed under conditions of indiscriminate savagery in Tito's notorious death marches and massacres. Throughout their journey the prisoners were beaten, tortured and killed, individually and in groups (Geiger 2013, pp. 77-80). These death marches frequently covered hundreds of miles and extended for many months' duration. Figure 3 identifies the routes of the death marches that have come to be known as the Croatian Way of the Cross (Ferenc and Kuzatko 2007, p. 36).

\section{Figure 3: Death Marches - An Overview of Main Routes of the Croatian Way of the Cross}

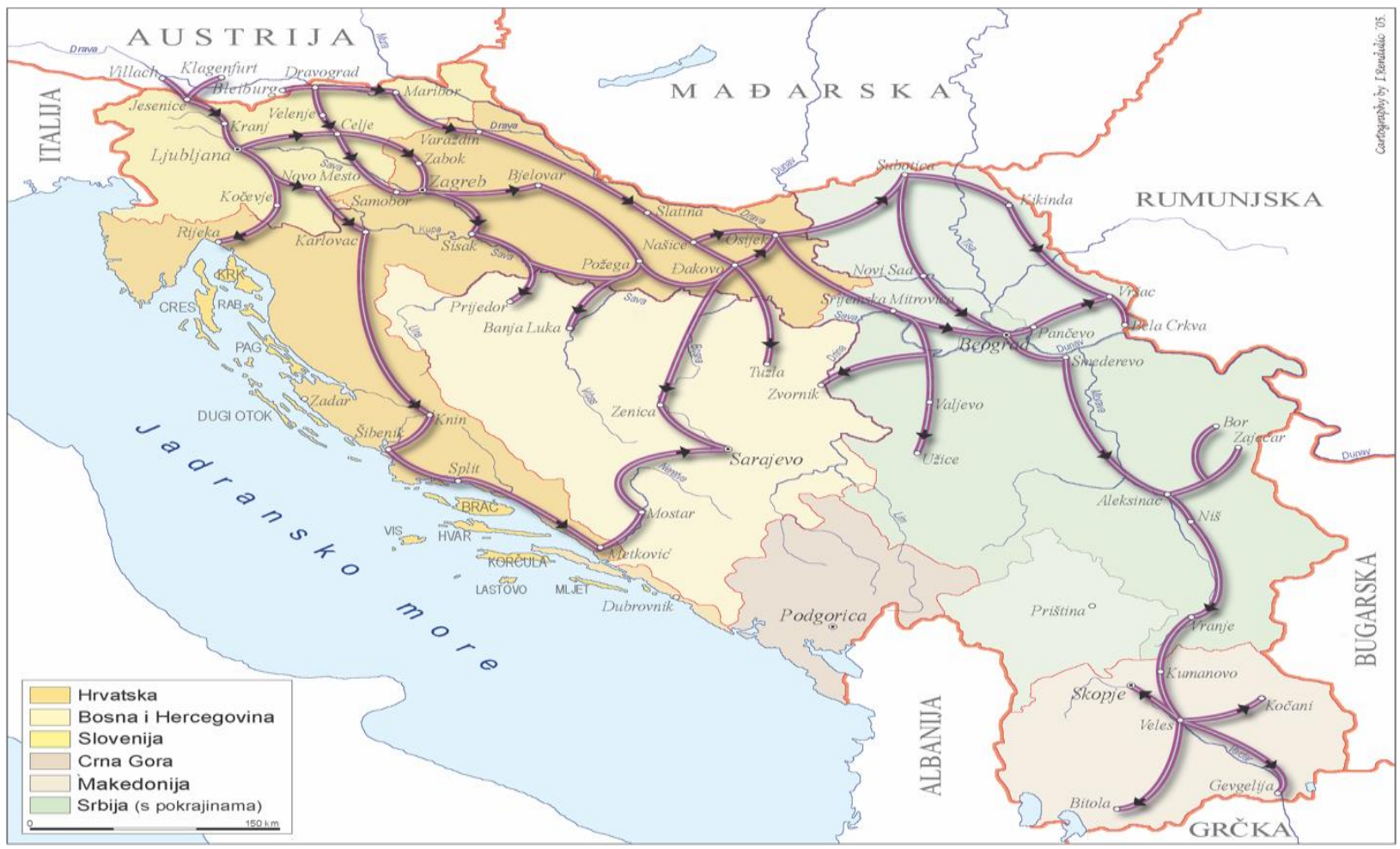

Source: Ferenc and Kuzatko 2007, p. 36

"Old Communists" selected extermination squads that carried out the wholesale massacres (Willoughby in Prcela and Guldescu 1995, xii; Dubajić 2005; Rulitz, p. 124). Descriptions of these events are documented through testimony of survivors, witnesses and perpetrators (Prcela and Guldescu 1995, pp. 125-535; Prcela and Zivić 2001). Recent figures uncovered by Roman Leljak from UDBA (secret police) files suggest that fewer than $10 \%$ of the individuals who sought asylum but were repatriated survived their ordeals (Pinter 2018). 
Simo Dubajić, then Deputy Head of the Operational Division of the 11th Dalmatian Partisan Brigade, who accepts personal responsibility for the deportation of prisoners to their deaths, in recorded testimony states:

In Kočevski Horn, approximately 40,000 Croats and 5,000 Slovenians were liquidated. About 8,000 people a day were transported by train from Bleiburg through Jesenica. They were categorized into three distinct categories, A, B and C. Classification in Categories B and C meant certain death. Liquidations were performed by volunteers of the 11th Dalmatian Partisan Brigade and the 26th Dalmatian Division of the Yugoslav Army (Dubajić 2005).

Every day on the Kočevski Horn, we executed between 5 to 6 trains of prisoners of war. The chiefs of the execution squad were Serbs Perisa Dinko and Pero Bozinović, who were the intelligence officers in the Yugoslav Army. Milka Planinc, then communist commissar and future secretary of the Communist Party of Croatia, sought voluntary liquidators. According to Partisan volunteer Juresad of the 11th Dalmatian Brigade, at the liquidation site Milka Planinc stuck a nail into a victim's head and said, "Did I finally get the Independent Croatian State out of your head?" (Dubajić 2005; Leljak 2017b).

Tito sent a commission of five officers under the command of a Serbian colonel to inspect the places where the bodies had been disposed. To cover up the sea of corpses, I resorted to extensive dynamiting of the terrain. I said: "Drop dynamite into the holes so no one can climb out." It was terrifying. Many of the Partisans lost their minds because of the mass murdering and torturing of the prisoners. When the chief Partisan [Periša] returned home, he killed his whole family, then himself (Dubajić 2005).

Records were set by the Yugoslav Partisans in Kočevski Horn: Ante Čepić from Makarska held first place, having killed 3,800 Croats. In second place with 3,000 victims was the Yugoslav Ljubo Periša from Sibenik. Third place was taken by Yugoslavia Ado Dragić who disposed of 2,200 unfortunates. Nikola Marić from Boka Kotorska, Milka Planinc and Simo Dubajić, held fourth and fifth place on the liquidator list with about 2,000 victims each (Leljak 2017b).

Dubajić states in interview:

After the liquidations, all of the liquidators of the 11th Dalmatian Partisan Brigade were rewarded with two weeks holiday on Lake Bled. They were presented with gold watches and cameras for their efforts (Dubajić 2005).

To lend credence to the veracity of his testimony, Dubajić explains:

From being an atheist, I have come to be a religious Orthodox Christian believer. I believe that confession of $\sin$ is the greatest human obligation and, in that sense, may be a condition for forgiveness of the crimes that I have committed. I want to 
confess the crimes in which I personally participated as an executioner or as issuer of the orders (Dubajić 2005).

According to historian John Ivan Prcela, as a young seminarian, then Partisan,

In Bazovica, I remember very clearly, even though the war was over, machine guns were at work continuously. The prisoners of war were killed. The place at which I experienced the Bleiburg tragedy is Foybeh. There were 400 Croatian prisoners of war, Italians and Germans, too, who were captured in Trieste. They are in that mass grave in Foybeh" (in filmed interview January 2017).

It was after witnessing atrocities that Prcela defected from the Partisans.

Djilas in his 1979 interview with Dr. George Urban explains:

We were an entirely new, brash, revolutionary force without a properly elected leadership, courts, and all the rest. Indeed, in 1945 we still went about detaining and executing people quite arbitrarily either for political reasons or for anything else we thought was culpable. Our basis of legitimacy was even thinner than that of the Soviet government (Tolstoy 1986, p. 356; Urban 1979, pp. 40-41).

He concludes:

Yes, the British did the wrong thing in putting these people back across the border, as we did completely the wrong thing in shooting them all. In my book Wartime I make no secret of my view that these killings were senseless acts of wrathful revenge (Tolstoy 1986, p. 356; Urban 1979, pp. 40-41).

When asked if he believed that Tito had authorized the massacres, Djilas responded:

Whether or not Tito had given direct orders, no one knows. But certainly, he was in favour of a radical solution -- for pragmatic reasons, as the British, too, had pragmatic reasons for returning these refugees. Yugoslavia was in a state of chaos and destruction. There was hardly any civil administration. There were no properly constituted courts. There was no way in which the cases of 20,00030,000 people could have been reliably investigated. So, the easy way out was to have them all shot, and be done with the problem (Tolstoy 1986, p. 357).

Djilas reports that he met with Tito in 1948:

Once in a rambling conversation--after the clash with the Soviet leadership in 1948, of course--I mentioned that we had gone too far then, because among the executed also were some fleeing for ideological reasons alone. Tito retorted immediately, as if he had long since come to a final, though hardly comforting, conclusion: 'We put an end to it once and for all! Anyway, given the kind of courts that we had...' (Djilas 1977, p. 449) 
Prime Minister and Commander in Chief Marshal Josip Broz Tito repeatedly called for the surrender of retreating columns. On May 9, 1945, one day after the surrender of all German forces, in a radio address from Belgrade, Tito threatened a "merciless response" should any collaborators refuse to surrender (Dizdar 2005, p. 135). Croatian-American historian Jozo Tomasevich notes that it should come as no surprise that there were excesses: "No mercy on the part of the Yugoslav Partisans toward these troops could have been expected" (2001, p. 113-4; Geiger 2013).

According to Dr.sc. Ivo Lucić, Croatian Institute of History, former Chief of the Security and Intelligence Agency of Bosnia and Herzegovina (in filmed interview, September 2016):

In September 1945, the American ambassador sent a request to the U.S. State Department that they halt any support of Yugoslavia until the Yugoslavs end the dictatorship and terrorism. The Secretary of the U.S. Embassy in Belgrade wrote on 27 September 1945: "Enormous fear pervades all of life in Yugoslavia. Secret police are watching everyone labeled an enemy of the regime. Many people are being taken into custody. Police have a list of those they know will not vote for the communist party. Compared with OZNA (the Partisan secret police), the Gestapo was a mild institution.

Dubajić confirms Tito's intention of dealing harshly with those he suspected of not supporting his position:

As soon as Tito assumed power, he set up concentration and slave labor camps throughout the country (Dubajić 2005).

As Willoughby summarizes: "Croatia became an immense graveyard--her ditches, ravines, forests, rivers all crowded with corpses" (Willoughby 1968 in Prcela and Guldescu 1995, xii).

German historian Florian Rulitz writes:

Postwar Yugoslavia was based on murder, liquidations during the war, mass killings of political opponents after the war, "cleansing" of the territory from class enemies, robbery and legalization of collective theft, physical violence, offenses against physical integrity and human dignity, police terror, deprivation of liberty by unlawful arrests, forced labor in concentration camps, political infringements into the professional environment of individuals as well as on fear, deceptions, and lies (2016, p. 124; see also Dizdar 2013, pp. 162-163; Rulitz 2015, p. 122). 


\section{Politics: Legacy of the Past for the Present}

In 1990, a group of Slovenian historians and journalists began the process of uncovering concealed mass gravesites in their homeland (Leljak 2015; Leljak 2017a; Leljak 2017b; Leljak 2017d). According to Dr. Mitja Ferenc, Associate Professor of History at the University of Ljubljana and member of the Commission of the Republic of Slovenia Government to Resolve the Issue of Concealed Mass Graves, whom the author interviewed in August 2016:

In these past 26 years as I worked at secret grave sites, I saw unbelievable things. But what I saw here in Huda Jama, such a horrific scene, I will never forget. We dug the gravesite for 8 months. There were 11 concrete walls that blocked our passage to the inside. The widest wall was 1.2 meters deep, supported by 11 iron rods. It was clear that they constructed it all together in such a way that no one would ever find out this horrible truth.

Dr. Ferenc, the son of a noted historian and Partisan leader, continues:

After we walked a short distance, we stepped on a huge pile of human bodies. Those bodies were still intact, in one piece, you could see everything: skin, ears, hair. Later, we discovered there were eight rows of human bodies lying on top of one another. It seems that people were forced to lie down on the dead bodies below them before they were killed. In that single spot, we found 427 bodies.

Then, we dug deeper into the earth, around 5 meters, because we wanted to discover how many bodies were lying in a pit 45 meters deep. From this 5-meter sample we dug out 340 human bodies. When I emerged from the pit, I cried like a small baby (in filmed interview August 2016).

Dr. Ferenc and his colleagues carried out the excavations in secret, posing as members of a speleological society. He continues:

In 2009, 64 years after the massacre at Huda Jama, which has come to be known as the Devil's Pit, the long-concealed secret was revealed. The truth had been buried in the mine shaft for all of that time. When Huda Jama was finally fully excavated, the skeletons of more than 3,000 murdered men, women and children were found. Long braids still adorned the sculls of the women. In this place, in 1945, people were tortured, raped, mutilated, executed, and some buried alive.

Already in 2002, as head of the project Locating Hidden Grave Sites in the Republic of Slovenia, Dr. Ferenc assisted in locating 512 gravesites that were the result of mass killings in the war and post-war period (Ferenc 2007, p. 193). By 2016, he reported that more than 700 concealed grave sites had been identified (Times of Israel 2016). 
In interview, he described the public reaction to the discoveries:

When we revealed this Devil's Pit, the people of Slovenia and Croatia were horrified. Especially for us in Slovenia because we never heard or even read in foreign publications about such a place of execution. When the news emerged, the Slovenian government forbade excavation for the next 7 years (August 2016).

According to Dr. Jože Dežman, President of the Commission of the Government of the Republic of Slovenia to Resolve the Issue of Concealed Mass Graves, and since 2012 Director of the Archives of Slovenia:

Killing civilians and prisoners of war after the Second World War is the greatest massacre of unarmed people of all times in Slovenian territory. Compared to Europe, the Yugoslav communist massacres after the Second World War are probably in size and ferocity second only to the Stalinist purges and the Great Famine in the Ukraine. The number of those killed in Slovenia in the spring of 1945 can now be estimated at more than 100,000. Slovenia was the largest postWar killing site in Europe. It was a mixture of events, when in Slovenia there are retreating German units, collaborator units, units of the Independent State of Croatia, Chetniks and Balkan civilians; more than 15,000 Slovenian inhabitants were murdered as well. Because of its brevity, number of casualties, way of execution and massiveness, it is an event that can be compared to the greatest crimes of communism and National Socialism (Starič 2008, p. 204) [testimony at European Public Hearing on Crimes Committed by Totalitarian Regimes. Slovenian Presidency of the Council of the European Union (January-June 2008) and the European Commission].

Dr. Dežman, whose uncle was a commander of the Upper Carinthian UDBA (secret police) in 1945, participated in communist organizations as a young man. In the 1990s he became an active member of the liberal party. For the past two decades he has actively advocated for the inclusion of anti-Communist perspectives in Slovenian historiography (Dnevnik, 12 March 2012). In filmed interview in 2016, Dr. Dežman stated: "I believe that further analysis of these crimes will lead to the conclusion that Titoism was a genocidal system, because of the physical, political terror, as well as the killing of faith and spirit that amounted to a form of cultural genocide in Yugoslavia" (September 2016).

Dr. Ivan Lucić, former Chief of the Croatian Secret Intelligence Service, in filmed interview reported that

On the territory of Bosnia and Herzegovina, 24,000 Croatians were killed after the Second World War. That is $10 \%$ of the population. That is more than three times the number of people killed in Srebrenica in the recent war. The average age of those killed was 23 years. They killed all literate people--intellectuals, professors, teachers, priests. They killed 680 young people under the age of 15, and 817 women. From 1945 to 1951, the communists carried out terror against Croatian families in Herzegovina (in filmed interview, September 2016). 
Simo Dubajić explains that

The Communist Party of Yugoslavia under Tito, backed by the army and supervised by the secret police, had hopes that its rule would last forever. Tito's death in May 1980 opened a Pandora's box of problems within Yugoslavia. (Dubajić 2005).

Dr. Ferenc, who has written extensively about the concealed mass graves and the events following Bleiburg, states that in Slovenia there are many sites yet to be uncovered. He reports that as of 2008, official data substantiate 3,986 known wartime graves and mass graves in Slovenia from World War II (Ferenc 2008, p. 155), people executed en masse without a trial (Mikila 2008, p. 145).

In August of 2016, Dr. Ferenc accompanied the author to the cite of the Brezno massacre:

We stand here today at the site of the Brezno executions, near the city of Ljubljana. Here were buried the bodies of approximately 800 Croatian Homeland Guards. They were killed in 1945, after the war. Below this pit ran a river, so all livestock and people in this region contracted infections. That is why OZNA, the Partisan secret police, brought in some German prisoners of war who were ordered to dig out all the bodies and bury them three hundred meters away (in filmed interview; see also Lowe 2012, pp. 260-261).

According to the Commission on Concealed Mass Graves in Slovenia, the remains of victims of the May 1945 Tezno massacre were found in a 740-meter trench. Dr. Ferenc estimates that this largest mass grave of Croatians holds the remains of a minimum of 15,000 casualties (Ferenc 2012, p. 541; Radoš 2007; Glenny 1999, p. 530).

Croatian researcher Ante Beljo has contributed to our understanding of the widespread executions that occurred and the burial of victims even in and around the capital of Croatia, Zagreb. He showed the author one such site in beautiful Tuškanac public park in the center of Zagreb:

Here behind me is a mass grave of people who were killed in 1945 . The people executed were all civilian residents of the center of the city of Zagreb. Their only sin was that they were members of wealthy families. The Partisans killed them so that they could seize their property. To date, in the city of Zagreb and environs, we have discovered 180 mass graves (August 2016. See also Beljo 1985 and 1995).

Figure 4 provides the Slovenian government's map of thousands of mass graves in Slovenia and Croatia. 
Figure 4: Map of Mass Graves in Slovenia and Croatia

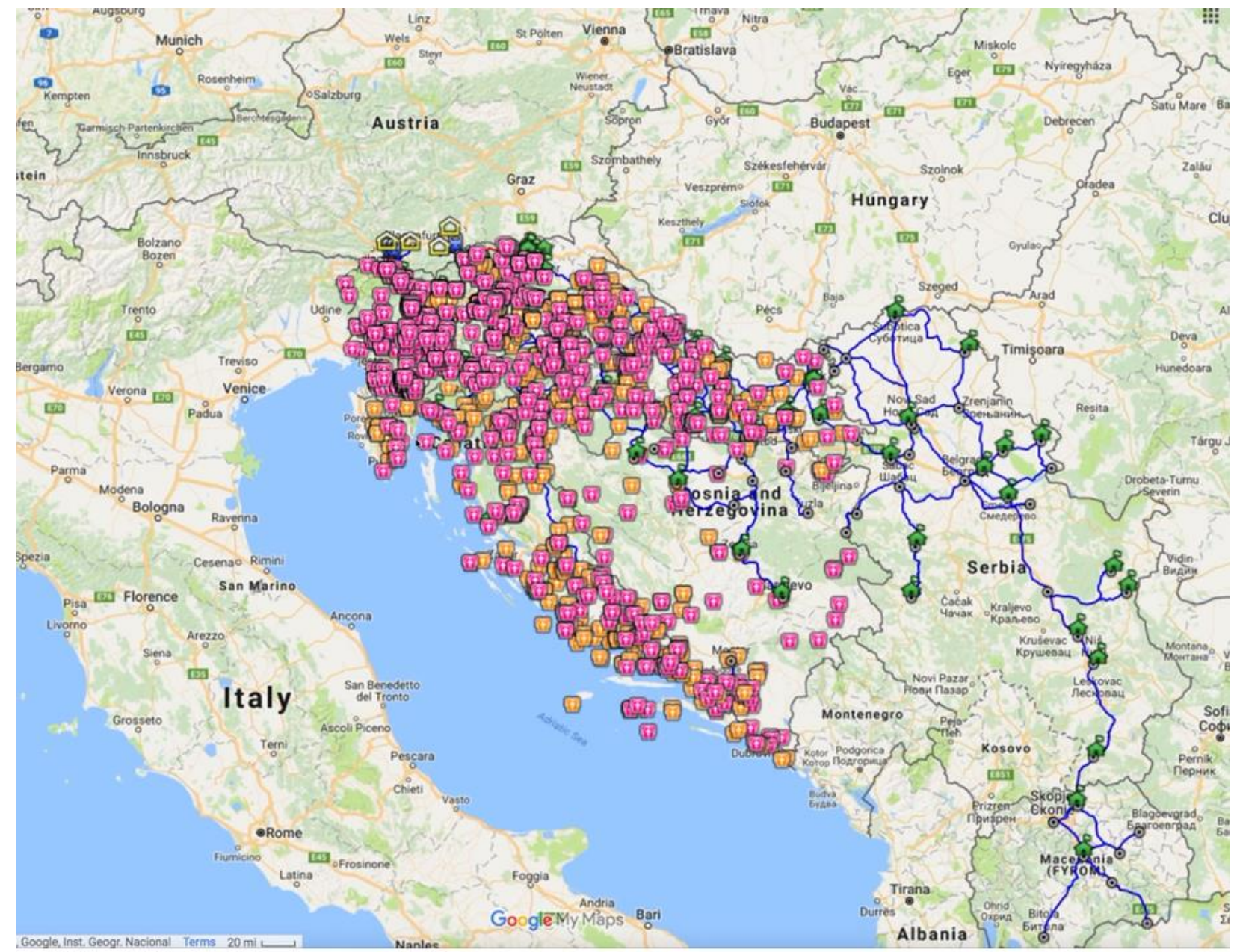

Source: Government of Slovenia

websitehttps://www.google.com/maps/d/viewer?mid=1acZ-

rROOvSr3kkgGXBZUsSLODbk\&ll=43.934691147267046\%2C18.12258350000002\&z=6

https://www.google.com/maps/d/viewer?mid=1g1BSoE4iyyk8ANAAiW9-

CIB7OIY\&II $=46.17537586752974 \% 2 C 14.95851950000008 \& Z=9$

Prosecutor Vice Vukojević, Judge of the Constitutional Court of the Republic of Croatia 1999-2007, explained in interview:

In October 1990, I urged passage of a law to identify the victims of the 2nd World War and its aftermath. On October 8, 1991, the Croatian Parliament voted to secede from Yugoslavia and they passed the law to identify the victims.... As a result of that law a Commission was established to identify all victims ... regardless of race, religion, politics, and military service....

I was the first president of this commission. It included 25 members of the Croatian parliament and 30 plus academics, historians, representatives of the media, etc. 
In 1992, we excavated a mass grave at Macelj in Croatia. I identified 12 possible suspects involved in these mass killings. The state prosecutor's office filed a lawsuit, the suspects were questioned, but nothing happened after that. The first grave we opened contained 101 skeletons. Everyone was younger than 18 years of age. In the second grave, we found 500 Home Guard soldiers who were killed in one night. The Commission concluded that more than 1,000 mass graves existed on the territory of Croatia. The Commission confirmed that genocide was committed against the Croatian people and that Josip Broz Tito was responsible for it. Following the release of this report in 2000, the Commission was suddenly abolished and funding was cut (in interview September 2016; Vukojević 1995, pp. 309-311).

Dr. Dežman concludes,

Tito killed the innocent victims and celebrated the perpetrators. The celebration of the People's Liberation Revolution was, in fact, a celebration of the crime. The history of Yugoslavia began with terrorist acts and ended with mass liquidations (in filmed interview August 2016).

In filmed interview Dr. Ferenc expresses his frustration with the slow progress that has been made in revealing the truth:

Our progress in addressing the issue of these mass grave sites, kept secret for 70 years, has been very slow. We started our research in 2002. Since 2009, when we discovered The Devil's Pit, we have found 600 mass graves on the territory of Slovenia. When we found The Devil's Pit, it was such a shock that we were forced to halt any further excavations until 2016 because of the political problems. No one truly supported what we were doing. Politicians had a few nice words for our efforts, but that was all we received.

I can understand that when we lived for 45 years under a one-party political system, all of this was hidden from us. This was a forbidden theme. But I ask myself, why now, when we have lived in a democracy for 26 years, do we remain silent? Why not address the issue and bring our actions and ourselves in line with civilized behavior? (September 2016).

Aleksandar Ranković created OZNA, the Partisan security agency. After World War II, he became minister of the interior and chief of the military intelligence agency UDBA that replaced OZNA. In the daily Politika of February 1, 1951, in his role as chief of the secret police, he reported that "Through our jails there passed from 1941 to $19513,777,776$ persons and we liquidated 568,000 enemies of the people" (1951, p. 1). This statement confirms that Tito's "henchmen did not limit their slaughterhouse tactics to members of the Croatian Army or its civilian followers" (Willoughby 1968 in Prcela and Guldescu 1995, xii). Between 1945 and 1990, recent data reveal that the communists interrogated 3.8 million people. "Hundreds of thousands of citizens of all ages, sexes, from every walk of life were imprisoned, tortured and finally liquidated (Willoughby 1968 in Prcela and 
Guldescu 1995, xii). They endured terror and trauma, war crimes of rape, crimes against freedom, and disregard of the laws of the state and humanity. In the 49 years of the Yugoslavian state's existence, documents suggest that the communists killed more than a million people. With that Tito's rule earned a place on the list of the most murderous regimes of all time (Jones 2014).

Croatian researcher Beljo confirms that "Today, fear still exists. Some witnesses are still alive, but people do not want to be victims again, for simply telling the truth" (in filmed interview August 2016).

The legacy of the past has haunted this region. Dr. Dežman reminds us:

All of the crimes committed in Tito's name from 1940 to 1980, we saw repeated again, during the last war in the Balkans, 1991 to 1995. The message of the Ovčara massacre [torturing and killing of $200+$ hospital patients by Serbians] in the recent war is identical to the message of the horrible massacre of Huda Jama, the Devil's Pit, in 1945.

The last blood that was shed during the break-up of Yugoslavia is associated with the first blood that was shed at its birth. Today before the International Tribunal for the Former Yugoslavia, there is a battle where we can see that the fight for truth and justice is exactly what it was in 1945. Just as the crimes were concealed after World War II, the crimes of the recent war are concealed as well. And just as the bodies of the Srebrenica victims have been excavated, now too are we excavating the bodies of the victims of 1945's massacre. Our great historical mission is to end the circle of blood that envelops us (in filmed interview September 2016).

As Bernd Posselt, President of the Pan-European Union in Germany and member of the European Parliament from 1994-2014, puts it:

From 1945, through the rarely mentioned period of Tito's prison islands, through the brutal crushing of the Croatian Spring, through the 1992 fall of Vukovar, there has been a continuous trail of blood. Nowhere has the transition come as late as in Yugoslavia and Croatia. I hope that we finally have the courage to depart from the totalitarianism of the past (in filmed interview August 2016).

Dr. Dežman poignantly ponders:

Of course, we have to wonder how it happened that after the Second World War in Yugoslavia at least a quarter of a million people were killed in a matter of a few months. The enormity of this crime naturally raises the fundamental question: How could this crime remain hidden? And how is it possible that the heirs of this crime and the criminals who perpetrated this crime, some of whom are still alive, have so persistently and successfully evaded truth and justice? This is the question we must constantly pose (in filmed interview September 2016). 


\section{Promulgation of International Law on Genocide, Protection of Refugees, Asylum Seekers, and Prisoners of War}

At the League of Nations on October 28, 1933, five countries signed the Convention on the International Status of Refugees, which has come to be considered the first document in international law that articulates the principle of non-refoulement, that is, the protection of refugees from forced repatriation in cases in which their lives might be in danger. Initially applied to Armenians and Russian refugees, the agreement guaranteed refugees access to Nansen Passports (identification and travel papers), the courts, education, welfare, and protection from exploitation.

Although the agreement was eventually adhered to by other countries, it wasn't until 1951 that the U.N. formally enshrined the principle of non-repatriation into international law with the signing of the U.N. Convention in Relation to the Status of Refugees, often referred to as the Refugee Convention. Article 33 sets forth the prohibition against nonrefoulement, "the expulsion or return of a refugee in any manner whatsoever to the frontiers of territories where his life or freedom would be threatened on account of his race, religion, nationality, membership of a particular social group or political opinion" (Goodwin-Gill 2014, p. 39; UNHCR 1951). The 1951 law grew out of collective memory of forced repatriations of Soviet and Yugoslav citizens, and, of course, the failure of countries to provide protection for Jews fleeing the Holocaust (Padmanabhan 2011, p. 73). The Refugee Convention builds on Article 14 of the 1948 Universal Declaration of Human Rights, which recognizes the right of persons to seek asylum from persecution in other countries (U.N. Declaration of Human Rights 1948).

The Geneva Conventions of 1949 stipulate that prisoners must be protected "against acts of violence," but they do not stipulate whether a country has the right to repatriate prisoners against their will. The Geneva Conventions suggest that "repatriation is a right, not an obligation" (Grahek-Ravančić 2006, p. 36).

A June 1955 U.S. Congressional Report by the Committee on Foreign Relations on the Geneva Conventions and the Protection of War Victims confirmed that one could not legally compel prisoners of war to be repatriated against their will. The report holds that in Geneva in 1949 it was determined that the doctrine of asylum is applicable (U.S. Congress 1955).

Numerous issues arise as we consider how to interpret the principle of non-refoulement. Countries have interpreted the principle in various ways. All interpretations relate to our tale of the forced repatriation of asylum seekers from Croatia and Slovenia:

- 'Strict' interpretation applies to individuals who have actually entered a country's borders.

- 'Strict with a narrow reading' requires that the individual's "life or freedom would be threatened" were they to be returned to their country of origin. 
- The 'Collectivist' approach does not require that the individual remain in the country where they sought asylum, allowing for them to be redistributed to other countries, but not returned to the country where they face dangers.

- Another 'Collectivist' interpretation allows for the establishment of non-sovereign zones/travel hubs within the country where they sought asylum. From there they can be sent to other countries, but not where they would face danger (D'Angelo 2009, p. 279).

The 1967 Protocol Relating to the Status of Refugees extended the protection temporally and geographically to protect individuals after 1951 and on continents other than Europe.

Today, the forced return of people to countries where they would face persecution violates international law. International law protects prisoners of war, civil detainees and refugees refusing repatriation from forced return, particularly if their refusal to return is motivated by fears of political persecution in their own country. International law requires that they be granted temporary or permanent asylum (Zieck 1997, p. 147).

In 2006, the Parliamentary Assembly of the Council of Europe considered Resolution 1481, titled The Need for International Condemnation of Crimes of Totalitarian Communist Regimes.

The Council of Europe resolution condemns the massive human rights violations committed by totalitarian communist regimes and expresses sympathy, understanding and recognition for the victims of these crimes. These violations include individual and collective assassinations and executions, death in concentration camps, starvation, deportations, torture, slave labor and other forms of mass physical terror (Council of Europe, Parliamentary Assembly 2005).

While the resolution was supported by the overwhelming majority of the members of the Political Affairs Committee, it did not receive the necessary two-thirds majority of the votes cast in the Parliamentary Assembly. The resolution was blocked by countries where the former communist ruling class and secret services continue to exercise political and economic power, even where it may outwardly appear they have thrown off that yoke.

The forced repatriation of refugees to Yugoslavia at the close of World War II resulted in mass genocide, as, of course, did the actions of the Nazis toward Jews and other ethnic, religious and political groups throughout the war, but it was only on December 11, 1946 that the United Nations General Assembly voted unanimously to declare genocide a crime under international law. In 1948, they voted unanimously to create the U.N. Convention on the Prevention and Punishment of the Crime of Genocide. Recognizing that "at all periods of history genocide has inflicted great losses on humanity" and that international cooperation is needed "to liberate mankind from this odious scourge," the Convention criminalized acts committed with the intent to destroy ethnic, national, racial, or religious groups (United Nations Human Rights Office of the High Commissioner 1948). 


\section{Conclusion}

As we examine the tragedy of Bleiburg, the analysis provided by Professor Emeritus Gerald Draper, a Nuremberg War Crimes Prosecutor who was a Senior British Officer in World War II occupied Germany, puts the issues into sharp focus:

Assuming that at the time these incidents happened in the second half of May, perhaps later, of 1945, if Croatia was at that time operating in any way even as the vestiges of the state, and acting in close concert with Germany as a co-belligerent, the Tito administration which murdered them, including their women and children, and shot them in cold blood, might well be exposed to what we would call a war crime.

Assuming that wasn't there and Croatia had long since lost the last vestiges of statehood and organization as a belligerent, it would undoubtedly be possible to task Tito with a crime against humanity because that would extend to any population connected with the war and this was a population of those particular people and it was connected with the war, so it's the second result there.

Thirdly, what has to be considered, is the question of whether or not any person on the British end of this tragedy, military, civilian, that is ministerial or soldiery, British of any level who are shown to have been responsible either for forcible repatriation of these victims to a known fate such as killing in cold blood at the hands of the Tito authorities or refusing to accept them into British control and protection in circumstances in which it is perfectly apparent that they would fall into the hands of Tito adherents who would likewise be known as to be more likely to decimate them, there may be a serious question whether certain British people in positions of responsibility and knowledge may not properly be tasked with all kinds of war crimes (in filmed interview with Michael Palaich 1988).

Nikolai Tolstoy concludes that "One day... an obelisk will be raised...above the grave of the fallen in the glade at Kočevje. There, if true justice is done, it will bear the name not only of Josip Broz (Tito), but those of his principal British collaborators, without whose secretive aid the tragedy would never have taken place" (1986, p 207).

The 20th century has left deep scars on the consciousness of the inhabitants of Croatia, Slovenia, and Bosnia and Herzegovina. The cycle of violence and circle of blood continue to constrict the economic, moral and human development of the people and countries in this region. The legacy of lies, deception, silence and secrecy conspire against the future. It is in the interest of peace, justice, and human dignity that we offer this article. Without full disclosure of the crimes and criminals, the political future of the region remains uncertain and unstable. 


\section{Interviews:}

Ante Beljo, film interview conducted by Nikola Knez, September 2016

Dr. Jože Dežman, film interview conducted by Nikola Knez, September 2016

Milovan Djilas, interview conducted by George Urban, 1979

Professor Emeritus Gerald Draper, film interview conducted by Michael Palaich, 1988

Simo Dubaić, film interview conducted in 2005 with TV Slovenia, 20 January 2005

Dr. Mitja Ferenc, film interview conducted by Nikola Knez, August 2016

Capt. Colin Gunner, film interview conducted by Michael Palaich 1988

Dr. Martin Hrgovčić, film interview conducted by Nikola Knez and Dorothy McClellan, March 2016

Dr. Ivan Lucić, film interview conducted by Nikola Knez, September 2016

Andy Mihajlović, film interview conducted by Nikola Knez, September 2016

Capt. Nigel Nicolson, film interview conducted by Michael Palaich, 1988

Bernd Posselt, film interview conducted by Nikola Knez, August 2016

John Ivan Prcela, film interview conducted by Nikola Knez, January 2017

Vice Vukojević, film interview conducted by Nikola Knez, September 2016

\section{References}

Beljo, A. (1995). Yu-genocide: Bleiburg, death marches, UDBA (Yugoslav Secret Police). Toronto: Northern Tribune Publishing.

Beljo, A. (1985). Yugoslavia genocide: A documented analysis. Toronto: Northern Tribune Publishing.

Blažeković, M. (1988). Ministar i Pokolji. Prilog Pitanju odgovornosti Za Prisilno Vraćanje Ratnih Zarobljenika Poslije Drugog Svjetskog Rata. In: V. Nikolic, (ed.) Bleiburg: Uzroci i Posljedice, 1st ed. [Bleiburg: Causes and Consequences: Memorandum of the Fortieth Anniversary of the Tragedy] Zagreb: Knjiznica Hrvatske Revije, pp. 405-406.

Bleiburg: Tito's license for genocide. (2017). [Documentary Film] Corpus Christi, Texas: Nikola Knez.

British Foreign Office Headquarters 5th Corps, War Diary Intelligence Summary, May 1945, Sheet 8 . See Sviben, p. 153. In: A. Mijatović (ed.), Bleiburg 1945. - 1995., 1st ed. Zagreb: Hrvatska Matica Iseljenika/Croatian Heritage Foundation.

Council of Europe, Parliamentary Assembly (2005). Resolution 1481. [online] Available at: http:// www.assembly.coe.int/nw/xml/XRef/X2H-Xref-ViewHTML.asp?FilelD= 11097\&lang=en [Accessed 15 January 2018].

Crljen, D. (1966). Bleiburg, Hrvatska revije, XVI, Nos. 2-4: December 1966.

D'Angelo, E. (January 2009). Non-Refoulement: The Search for a Consistent Interpretation of Article 33, Vanderbilt Journal of Transnational Law. 42 (1): 279. PDF Available at: https://wp0.va nderbilt.edu/wp-content/uploads/sites/78/DAngelo-final_x.pdf [Accessed 14 January 2018].

Dežman, J. (2009). Terrible evil from caves of evil, Ljubljana: Druzina.

Dizdar, Z. (2005). Prilog Istrazivanju Problema Bleiburga i Kriznih Putova (u Povodu 60. Obljetnice) [An addition to the research of the problem of Bleiburg and the Way of the Cross (dedicated to their 60th anniversary)]. The Review of Senj (in Croatian). Senj, Croatia: City Museum Senj - Senj Museum Society 32(1) pp. 117-193.

Dnevnik (2012). Spletni Portret: Jože Dežman, Zgdovinar, Cigar Stric Je Bil Poveljnik Gorensjske Udbe [Split Portrait: Jože Dežman, A Historian Whose Uncle Was the Commander of the Upper 
Carinthian UDBA]. Dnevnik.si (in Slovenian) 19 March 2012. [online] Available at: https://www.dnevnik.si/1042517400/lokalno/1042517400 [Accessed 5 February 2018].

Djilas, M. (1977). Wartime, New York: Harcourt, Brace, Jovanovich.

Dubajić, S. (2005). Filmed January 21, 2005. Interview available at: http://hu-benedikt.hr/?p=75709 Accessed 27 December 2017.

Dubajić, S. (2006). Život, grijeh i kajanje: Od Kistanja do Kočevskog Roga [Life, sin and commitment: From Kistanje to Kočevski Horn] Novi Beograd, Bad Vilbel: Nidda Verlag.

Epstein, J. (1973). Operation Keelhaul: The story of forced repatriation from 1944 to the present. Old Greenwich, Connecticut: Devin-Adair.

Ferenc, M. and Kuzatko, Z. (2007). Hidden Croatian Mass Graves in the Republic of Slovenia. Zagreb: Pocasni Bleiburski Vod.

Ferenc, M. (2008). Secret World War Two Mass Graves in Slovenia. In: P. Jambrek, (ed.) Crimes Committed by Totalitarian Regimes. 1st ed. [pdf] Ljubljana: Slovenian Presidency of the Council of the European Union.Available at: http://www.mp.gov.si/fileadmin/mp.gov.si/pageuploads/mp.gov. si/PDF/poprava_krivic/Crimes_committed_by_Totalitarian_Regimes.pdf [Accessed 5 January 2018].

Ferenc, M. (2011). Sprave No Bo Nadomestil Domovinski Spomenik Sredi Ljubljane. Delo (in Slovenian), 6 November 2011. [Homeland Monument Replaced in the Middle of Ljubljana] [online] Available at: http://www.delo.si/zgodbe/sobotnapriloga/mitja-ferenc-sprave-ne-bo-nadomestil-domovinskispomenik-sredi-ljubljane.html\%20 [Accessed 6 January 2018].

Ferenc, M. (2012). Tezno - Najveće Prikriveno Grobište u Sloveniji. O Istraživanju Grobišta u Protutenkovskom Rovu u Teznom (Maribor) [Tezno - The Biggest Hidden Mass Burial Site in Slovenia. On the Research of the Hidden Burial Site in the Antitank Ditch in Tezno (Maribor)]. Journal of Contemporary History (in Croatian). Ljubljana: Oddelek za zgodovino Filozofske fakultete Univerze v Ljubljani. 44 (3), pp. 539-569. Available at: https://hrcak.src e.hr/95078?lang=en [Accessed 4 January 2018].

Geiger, V. (2013). Human Losses of Croats in World War II and the Immediate Postwar Period Caused by the Chetniks (Yugoslav Army in the Fatherland) and the Partisans (People's Liberation Army and the Partisan Detachment of Yugoslavia/Yugoslav Army) and the Yugoslav Communist Authorities: Numerical Indicators. Review of Croatian History. Croatian Institute of History. 8 (1) pp. 77-121 [online] Available at: https://hrcak.srce.hr/103223?lang=en [Accessed 2 January 2018].

Glenny, M. (1999). The Balkans: Nationalism, war and the great powers, 1804-1999. New York: Penguin Books.

Goodwin-Gill, G. (2014). The International Law of Refugee Protection. The Oxford handbook of refugee and forced migration studies. Oxford University Press. p. 39.

Grahek-Ravančić, M. (2006). Controversies about the Croatian Victims at Bleiburg. Review of Croatian History 2/1, pp. 27 - 46. Available at: http://docplayer.net/27204513-Controversies-about-thecroatian-victims-at-bleiburg-and-in-death-marches.html [Accessed: 7 February 2018].

Grahek-Ravančić, M. (2008). Izručenja Zarobljenika s Bleiburškog Polja i Okolice u Svibnju 1945 [The Handing Over of Prisoners from Bleiburg Field and its Surroundings in May 1945]. Croatian Journal of Contemporary History (in Croatian). Zagreb, Croatia: Croatian Institute of History. 39 (3) pp. 531550 [online] Available at https://hrcak.srce.hr/index.php?show=clanak\&id_clanak_jezik=29735 \&lang=en [Accessed: 14 January 2017]. 
Grahek-Ravančić, M. (2009). Bleiburg i križni kut 1945: Historiografija, publicistika i memoarska literatura [Bleiburg and the death marches 1945: Historiography, journalism and memoirs] (in Croatian). Zagreb: Hrvatski institut za povijest [Croatian Institute of History] [online] Available at: http://www.znaci .net/00003/658.pdf [Accessed 5 February 2018].

Hale, C. (2001), What is Activist Research? University of Texas SSRC, Vol. 2, No. 1-2, 2001, pp. 13-15. Available at: https://issuu.com/ssrcitemsissues/ docs/i_i_vol_2_no_1-2_2001. [Accessed: 31 January 2018].

Haraway, D., (1988) Situated Knowledges: The Science Question, Feminist Studies 14(3) pp. 573-599. https://doi.org/10.2307/3178066

Jareb, J. and Omrčanin, I. (1977-1978). The End of the Croatian Army at Bleiburg, Austria in May 1945 According to English Military Documents, Journal of Croatian Studies, Vol. XVIII-XIX.

Jones, N. (2014). From Stalin to Hitler, the Most Murderous Regimes in the World, Daily Mail, 7 October 2014. [online] Available at: http://www.dailymail.co.uk/home/moslive/article-2091670/HitlerStalin-The-murderous-regimes-world.html [Accessed 12 December 2017].

Knez, N. (2017). Bleiburg: Tito's license for genocide [Documentary Film]. Corpus Christi, Texas: iFilms LLC.

League of Nations (1933). Convention of 28 October 1933 Related to the International Status of Refugees. Migration Education. p. 2. [online] Available at: https://www.wdl.org/en/item /11580/view/1/1/ [Accessed 14 January 2018].

Leljak, R. (2017a). Buried alive: Mass killings of POWs and civilians by Tito's Partisans, Createspace Independent Publishing Platform.

Leljak, R. (2017b). One Place of Execution of More Than 40,000 Innocent Croats, 7 Dnevno, 14 April 2017. Available at: https://inavukic.com/2017/04/15/one-place-of-execution-of-more-than-40000-innoc ent-croats/ [Accessed 7 February 2018].

Leljak, R. (2017c). Moj Novi Film Donosi Izjave Partizantskih Komandanata i Likvidatora o Tome Kako Se Ubijalo [My New Film Provides the Statements of the Partisan Commanders and the Liquidators on How They Killed]. Available at :https://kamenjar.com/roman-leljak-moj-novi-film-donosi-izjavepartizantskih-komandanata-likvidatora-o-tome-kako-se-ubijalo/ [Accessed 27 December 2017.]

Leljak, R. (2017d). Maribor: Najveće stratište Hrvata [Maribor: The largest gravesite of Croatians]. [Documentary Film]. Ljubljana: Hrvatska Udruga Benedikt i Udruga Huda Jama [Croatian NGO Benedict and NGO Huda Jama].

Leljak, R. (2015). Huda Jama. Ljubljana: Hrvatsko žrtvoslovno društvo.

Ljerkić, A. (1963). Od Ivan Planine do Bleiburga - Dokumenti o ovlačenju Hrvatske vojske 1945 godine [From Ivan Mountain to Bleiburg - Documents on the withdrawal of the Croatian Army in 1945]. Madrid: Drina.

Lowe, K. (2012). Savage continent - Europe in the Aftermath of World War II. New York: Macmillan.

MacDonald, D. (2003). Balkan holocausts?: Serbian and Croatian victim-centered propaganda and the war in Yugoslavia. Manchester University Press. https://doi.org/10.7228/manchester/9780719064661.001.0001 
Marović, J. (ed.) (1995). Od Bleiburga do naših dana [From Bleiburg to our current time].1st ed. Zagreb: Školska Kniga.

McAdams, C. M. (1995). Yalta and The Bleiburg Tragedy. In J. Marović (ed.) Od Bleiburga do Naših Dana, 1st ed. pp. 93-101, Zagreb: Školska Kniga. [online] Available at: https://web.archive. org/web/20130 816025402/http://www.ess.uwe.ac.uk/genocide/yugosl av-hist1.htm [Accessed 4 February 2018].

Mijatović, A. (ed.) (1995). Bleiburg 1945. - 1995. 1st ed. Zagreb: Hrvatska Matica Iseljenika/Croatian Heritage Foundation.

Mikola, M. (2008). Concentration and Labour Camps in Slovenia. In: P. Jambrek, (ed.) Crimes Committed by Totalitarian Regimes, 1st ed. [pdf] Ljubljana: Slovenian Presidency of the Council of the European Union [online] Available at: http://www.mp.gov.si/fileadmin/mp.gov.si/pageuploads /mp.gov.si/PDF/poprava_krivic/Crimescommittedby_Totalitarian_Regimes.pdf [Accessed 4 February 2018].

Musgrove, D., ed. (2009). BBC History Magazine, Falsified Yugoslav Handover to Tito. Bristol: BBC Worldwide Publications.

Obrdalj, T. (1995). "Kolona Duha Više od 70 Kilometara" ["A Column Over 70 Kilometers Long"]. In: A. Mijatović (ed.), Bleiburg 1945. -1995., 1st ed. Zagreb: Hrvatska Isljenika/Croatian Heritage Foundation.

Padmanabhan, V. (2011). To Transfer or Not To Transfer: Identifying and Protecting Relevant Human Rights Interests in Non-Refoulement. Fordham Law Review 80, pp. 73-123.

Palaich, M. (1991). Bleiburg tragedy [Documentary Film]. Scottsdale: A Michael Palaich Production.

Pavlowitch, S. (2008). Hitler's new disorder: The Second World War in Yugoslavia. New York: Columbia University Press.

Pinter, Z. (2018). Roman Leljak--Istrazivac Koji je Zaduzio Hrvate [An Investigator Who Has Overwhelmed Croatians]. Croative Kultura i Politika [online] Available at: https://croative.net/roman-leljakistrazivac-zaduzio-hrvate/ [Accessed 4 February 2018].

Prcela, J. (1995). The Work of the Cleveland Committee for Research on the Bleiburg Tragedy. In A. Mijatović (ed.), Bleiburg 1945. - 1995., 1st ed. pp. 301-308. Zagreb: Hrvatska Matica Iseljenika/Croatian Heritage Foundation.

Prcela, J. and Guldescu, S. (eds.) (1970). Operation Slaughterhouse: Eyewitness Accounts of Postwar Massacres in Yugoslavia. Philadelphia: Dorrance.

Prcela, J. and Guldescu, S. (eds.) (1995). Operation Slaughterhouse: Eyewitness Accounts of Postwar Massacres in Yugoslavia. Philadelphia: Dorrance.

Prcela, J. and Živić, D. (2001). Hrvatski holokaust [Croatian Holocaust] (in Croatian). Zagreb: Hrvatsko društvo političkih zatvorenika.

Portmann, M. (2004). Communist Retaliation and Persecution on Yugoslav Territory During and After World War II (1943-1950). Tokovi istorije. Institut za noviju istoriju Srbije (1-2), pp. 45-74. [online] Available at: https://www.ceeol.com/search/article-detail?id=212765 [Accessed 4 February 2018].

Radelić, Z. (2016). 1945 in Croatia, Review of Croatian History. Hrvatski institut za povijest (1): pp. 9-66. [online] Available at: https://www.ceeol.com/search/article-detail?id=470839 [Accessed 4 February 2018]. 
Radoš, I. (2007). Tezno Je Najveca Masovna Grobnica Hrvata (in Croatian) [Tezno is the Largest Mass Grave of Croatians]. Jutarnji List [online] Available at: https://www.jutarnji.hr/arhiva/tezno-jenajveca-masovna-grobnica-hrvata/3960183/September 11, 2007. [Accessed 5 February 2018].

Ranković, A. (1951). Politika, February 1, 1951. [online] Available at: https://www.facebook .com/ antifavjesnik/photos/a.1544327215819325.1073741828.1544316125820434/1670683139850398 /?type=3\&theater and http://www.forum.tm/vijesti/cicak-lazno-citirao-rankovica-u-otvorenom-o-58 6000-likvidiranih-narodnih-neprijatelja-5836 [Accessed 14 January 2018].

Rulitz, F. (2016). The tragedy of Bleiburg and Viktring, 1945. Dekalb: Northern Illinois Press.

Sanders, J., Sauter, M., and Kirkwood, R. (1992). Soldiers of misfortune: Washington's secret betrayal of American POWs in the Soviet Union. National Press Books.

Starič, J. (ed.) (2008). European Public Hearing on Crimes Committed by Totalitarian Regimes. Ljubljana: Slovenian Presidency of the Council of the European Union.

Sviben, K. (1995). Predsjednik Komisije za Utvrdivanje Ratnih i Poratnih Zrtava, Zavrsna Rijec, i Documenti o Bleiburgu [President of the Commission for the Identification of Second World War and Post-War Victims, Concluding Remarks, and Documents about Bleiburg]. In Mijatović, A. (ed.), Bleiburg 1945. - 1995., 1st ed. Zagreb: Hrvatska Matica Iseljenika/Croatian Heritage Foundation. pp. 145166, pp. 312-313.

Times of Israel (2016). Slovenia Transfers Mass Grave Remains of Nazi Collaborators (6 October 2016). Available at: https://www.timesofisrael.com/slovenia-transfers-mass-grave-remains-of-nazi-collab erators/ [Accessed 7 February 2018].

Tolstoy, N. (1986). The minister and the massacres. London: Century Hutchinson Ltd.

Tolstoy, N. (1977). Victims of Yalta: The secret betrayal. New York: Charles Scribner's Sons.

Tomasevich, J. (2001). War and revolution in Yugoslavia, 1941-1945: Occupation and collaboration. San Francisco: Stanford University Press.

United Nations High Commissioner for Refugees (1951). Convention and Protocol Relating to the Status of Refugees, UNHCR [online] Available at: http://www.ohchr.org/EN/Professional Interest/Pages StatusOfRefugees.aspx [Accessed 14 January 2018].

United Nations Human Rights Office of the High Commissioner (9 December 1948). Convention on Prevention and Punishment of Genocide [online] Available at: http://www.ohchr.org/ EN/Profes sional Interest/Pages/CrimeOfGenocide.aspx [Accessed 5 February 2018].

United Nations Human Rights Office of the High Commissioner (1948). United Nations Declaration of Human Rights (1948). [online] Available at: http://www.un.org/en/universal-declaration-humanrights/ [Accessed 15 January 2018].

Urban, G. (1979). A Conversation with Milovan Djilas. Encounter, pp. 10-43 (December 1979). [online] Available at: http://www.unz.org/Pub/Encounter-1979dec-00010 [Accessed 5 February 2018].

U.S. Congress (1955). U.S. Congressional Report by the Committee on Foreign Relations on the Geneva Conventions and the Protection of War Victims [online] Available at: https://www.loc. gov/rr/frd/Military_Law/pdf/GC-senReport.pdf) [Accessed 15 December 2017]

Vetrinjska tragedija: $V$ spomin nesmrtnim junakom, izdanim u Vetrinju od 27. - 31. maja 1945. in pomorjenim za velike ideje svobode (1960) [Vetrinjska tragedy: In memory of the immortal heroes, 
issued in Vetrin from 27-31 May 1945 and murdered for the great ideas of freedom]. Cleveland: Zveza slovenskih protikomunističnih borcev [Slovenian Society of Anti-Communist Fighters].

Vlahović, S.R. (1985). Zbornik dokumenata iz Britanske arhive. [Collection of documents from British archives] Available at: https://openlibrary.org/books/OL2760938M/Zbornik_dokumenata_iz_Brita nske_arhive [Accessed 31 January 2018].

Vukojević, V. (1995). We Must Identify All World War II and Postwar Victims. In: A. Mijatović, (ed.) Bleiburg 1945. - 1995., 1st ed., pp. 309-311. Zagreb: Hrvatska Matica Iseljenika/Croatian Heritage Foundation.

Willoughby, C. (1995). Foreword to J. Prcela and S. Guldescu, (eds.) Operation Slaughterhouse: Eyewitness Accounts of Postwar Massacres in Yugoslavia. Philadelphia: Dorrance.

Zieck, M., UNHCR and voluntary repatriation of refugees: A legal analysis, Martinus Nijhoff Publishers, 1997, p. 147. 